\title{
Preliminary analysis of the cost effectiveness of rainwater tanks rebate scheme in Greater Melbourne, Australia
}

\author{
S. Gato-Trinidad ${ }^{1} \&$ K. Gan ${ }^{2}$ \\ ${ }^{I}$ Faculty of Engineering \& Industrial Sciences, \\ Swinburne University of Technology, Australia \\ ${ }^{2}$ Yarra Valley Water, Australia
}

\begin{abstract}
The Victorian Government in Australia through 'The Water Smart Gardens and Homes Rebate Scheme' provides rebates to residential water users who are connected to a mains water supply for purchasing water-saving devices and services to reduce their water consumption. Households who purchased and installed rainwater tanks from 1 January 2007 are eligible for a rebate of up to $\$ 1000$ per household depending on the size of the tank and connection for indoor water uses, such as for toilet flushing and clothes washing. This report presents the preliminary analysis of the cost effectiveness of the rainwater tanks' rebate scheme to the Victorian Government and to individual household owners who availed this scheme. The study involves the analysis of water consumption before and after the installation of rainwater tanks of 4391 households who availed the government rebates and of 4400 households who did not avail the scheme. Using the data provided by Yarra Valley Water the water savings from different tank's sizes were calculated from the households who installed the rainwater tanks and received rebates. The results revealed that the 4400 households used less water than those that received government rebates before the installation of rainwater tanks but after the installation their water usage surpassed those that installed rainwater tanks. The results also show that rainwater tank sizes with indoor plumbing have longer payback period than those solely for outdoor purposes due to higher capital and operating costs even with higher rebates from the government.
\end{abstract}

Keywords: rainwater tanks, cost effectiveness, payback period, water savings, Melbourne, Australia. 


\section{Introduction}

The Victorian Government through 'The Water Smart Gardens and Homes Rebate Scheme' rewards residential water users who are connected to a mains water supply for purchasing water-saving devices and services to reduce their water consumption. Households who purchased and installed rainwater tanks since 1 January 2007 are eligible for a rebate of up to $\$ 1000$ per household, depending on the size of the tank and connection for indoor water uses, in particular for toilet flushing and clothes washing. Different levels of savings in potable water may be expected for different tank size/ configurations.

This report presents the results of the preliminary analysis conducted on the cost effectiveness of the rainwater tanks rebates provided by the Victorian Government to a number of Melbourne households. The cost effectiveness of the rainwater tank rebate scheme was assessed from the point of view of both the government and the customers. Using the data provided by Yarra Valley Water (YVW), the water savings from different tank's sizes were calculated from the households who installed the rainwater tanks and received rebates. A comparison of water consumption between households with rainwater tanks and those without in some suburbs in Melbourne was also undertaken to determine the benefit of rolling the rainwater tanks rebates scheme to households who are currently not under the scheme.

\subsection{Study area}

Melbourne is the capital city of Victoria, Australia and the major residential, commercial and manufacturing centre for the state. It is the second largest city in Australia and has about $73 \%$ of the state's population (Figure 1). An estimated 4 million people resides in Melbourne in June 2008, an increase of 74,600 people or $2.0 \%$ since June 2007. Melbourne experienced the largest growth of all Australian capital cities for the year to June 2008 [1]. The average household size in Greater Melbourne is 2.59 in 2006 and is projected to decrease to 2.50 by 2018 [2].

Across metropolitan Melbourne, the climate is temperate with warm dry summer and a moderate winter rainfall. The average daily maximum temperature is about $26^{\circ} \mathrm{C}$ in summer, with extremes of $40^{\circ} \mathrm{C}$ or more, in most years. There is little variation across the city in temperature, except in small areas of higher elevation, where temperature is usually marginally lower.

The annual rainfall ranges from about $550 \mathrm{~mm}$ in the West of the suburban areas, to about $900 \mathrm{~mm}$ in the East. Until the mid 1990s, Melbourne had relatively reliable rainfall. Since then, there has been some of the lowest rainfall on record across a large part of Victoria including Melbourne. Rainfall recorded at Melbourne's reservoir sites for the 2007/08 financial year was $13 \%$ to $26 \%$ lower than the 30-year average (1978 to 2007) [3]. 


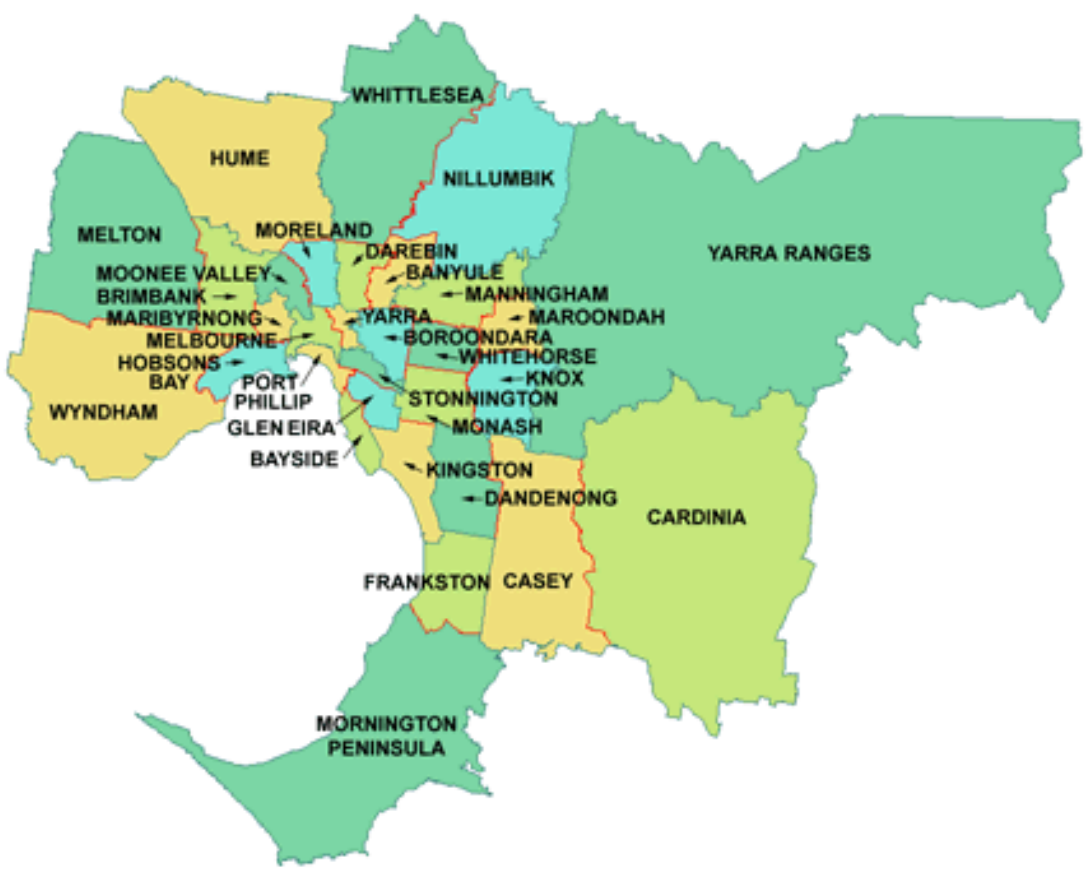

Figure 1: Greater Melbourne.

Due to low rainfall, the average inflows over the last 11 years have been $35 \%$ lower than the long term average inflow (1913 to 2008). Inflows to Melbourne's four major harvesting storages for $2007 / 2008$ were $340 \mathrm{GL}, 11 \%$ less than the average over the last 11 years and $42 \%$ less than the long term average. Around $80 \%$ of Melbourne's drinking water comes from closed water catchments in the Yarra Ranges (Yarra and Thomson River catchments) with the remainder extracted directly from the Yarra River or diverted from the Goulburn River Basin [3].

The average annual total consumption for Melbourne is estimated at $480 \mathrm{GL}$ [4]. Residential use accounted for $60 \%$, while commercial and industrial use accounted for around $28 \%$. The remainder is made up of a number of components such as water used for fire fighting, leakage and theft.

Since 2007/08 the annual consumption declined to $345 \mathrm{GL}$ due to water restrictions in place (Stages 1 to $3 \mathrm{~A}$ ) and the introduction of Target 155 in Dec 2008.

\section{Literature review}

Rainwater tanks can save a significant amount of water mains use. There have been a number of studies conducted in Australia and overseas on possible water savings and the cost benefits from installation of rainwater tanks. However, these studies were either a hypothetical study or based on limited number of data 
which restrict household owners or a government to make informed decisions on whether to have rainwater tank installed or to continue with the rainwater tank rebate scheme respectively.

Potential water savings depend on roof area, household size and the size of the rainwater tank. Rahman et al. [5] concluded that the most favourable financial condition for a $75 \mathrm{~kL}$ rainwater harvesting system is a benefit cost ratio of 1.39. This is based on a fictitious multistory building in Sydney, Australia with a $1600 \mathrm{~m}^{2}$ roof area, a nominal discount rate of $5 \%$, a water price of Aud $\$ 1.634 \mathrm{~kL}^{-1}$ and an inflation rate of $4.5 \%$ per annum. This means that the benefit cost ratio is subject to changes in the roof area of the house, the prevailing discount rate, the water price and the inflation rate.

Larger rainwater tank means more possible water savings as reported by Coombes and Kuczera [6]. An evaluation of the performance of 1-10 kL rainwater tanks for small dwellings in four Australian capital cities revealed that the water mains savings per year of $1 \mathrm{~kL}$ and $10 \mathrm{~kL}$ rainwater tanks ranged from $18-35 \mathrm{~kL}$ and $25-144 \mathrm{~kL}$ respectively [6].

An investigation conducted in Sweden revealed that possible savings of $30 \%$ of the total mains water consumption can be achieved from a $40 \mathrm{~kL}$ rainwater tank and large roof areas with indoor plumbing for toilet flushing and laundry [7].

\section{Methodology}

\subsection{Data collection}

Yarra Valley Water (YVW) provided the following data used in the analysis:

- Water consumption before and after the installation of rainwater tanks of 4391 households in Greater Melbourne which received government rebates and the corresponding rainwater tanks sizes. The water consumption data is on quarterly basis starting July 2005 to April 2010.

- Water consumption of 4400 households who did not avail the government's rainwater tank rebates. These households were chosen based on the similarity of their consumption patterns to the 4391 households prior to their tank installations.

The cost of rainwater tanks and associated installation as well as ongoing and extra maintenance costs were based on Tam et al. [8] and Marsden Jacob Associates [9] reports.

\subsection{Cost effectiveness of rainwater tanks scheme to customers}

The cost benefit of the scheme to customers was calculated by comparing the water consumption of each household before and after the installation of rainwater tanks (with 12 quarters gap in between). The dollar value of the water savings was calculated using YVW price structure. The average payback period was determined using the average water savings and the cost of rainwater tank, its installation, and ongoing maintenance from these households. 


\subsection{Cost effectiveness of rainwater tanks rebate to the Victorian Government}

The cost benefit of the rainwater tanks rebate scheme to the Victorian Government was calculated by comparing the total amount given to customers as rebates for installing rainwater tanks and the water savings achieved due to the rainwater tanks installation. The 4400 households without rainwater tanks were used as a control group to determine the amount of water savings that can be achieved if rainwater tanks will be rolled out further to these households.

\section{Results and discussion}

\subsection{Tank sizes, costs and installation}

There are different types and sizes of rainwater in Australia from small rainwater tanks, slim line tanks, under deck rainwater tanks, bladder tanks, underground poly tanks and underground concrete tanks. The capacities of these rainwater tanks range from 200L to 45,000L [10]. The costs of rainwater tanks also vary depending on their sizes and types. In this study, rainwater tank sizes were based on YVW groupings as shown in Table 1. The groupings were made in order to determine the water savings and the cost benefit of each rainwater tank size group. The result from this grouping will assist the Victorian Government and the household owner to determine which tank size group is more cost effective.

The prices of rainwater tanks shown in Table 1 are based on average price of the respective range sizes [10]. The costs for installation and plumbing were assumed to be the same for all sizes of rainwater tanks. The cost of the pump was added to a rainwater tank system which required indoor plumbing.

\subsection{Annual maintenance cost}

The annual maintenance cost adopted in this study is composed of any maintenance of operation of the rainwater tank system at \$20 and the annual energy costs of pumping for those with indoor connections of 5 cents per kilolitre of water pumped [11].

Table 1: $\quad$ Rainwater tanks sizes and installation costs in Melbourne, \$.

\begin{tabular}{|c|c|c|c|c|c|c|c|c|c|}
\hline \multirow[b]{2}{*}{ Item } & \multicolumn{6}{|c|}{ For outdoor use only } & \multicolumn{3}{|c|}{ For indoor \& outdoor use* } \\
\hline & $\begin{array}{c}600- \\
1000 \mathrm{~L}\end{array}$ & $\begin{array}{l}1001- \\
1700 \mathrm{~L}\end{array}$ & $\begin{array}{l}1701- \\
2250 \mathrm{~L}\end{array}$ & $\begin{array}{l}2251- \\
3600 \mathrm{~L}\end{array}$ & $\begin{array}{l}3601- \\
4500 \mathrm{~L}\end{array}$ & $>4501 \mathrm{~L}$ & $\begin{array}{l}2000- \\
4999 L\end{array}$ & $5000 \mathrm{~L}$ & $5000 \mathrm{~L}$ \\
\hline Tank & 570 & 680 & 960 & 965 & 1200 & 1520 & 870 & 1260 & 1260 \\
\hline Installation & 550 & 550 & 550 & 550 & 550 & 550 & 550 & 550 & 550 \\
\hline Plumbing & 730 & 730 & 730 & 730 & 730 & 730 & 730 & 730 & 730 \\
\hline Pump & 0 & 0 & 0 & 0 & 0 & 0 & 355 & 355 & 355 \\
\hline Total & 1850 & 1960 & 2240 & 2245 & 2480 & 2800 & 2505 & 2895 & 2895 \\
\hline
\end{tabular}

Note: *rainwater is also used for toilet and/or laundry. 


\subsection{Water savings}

The average water savings per year for each tank size group was calculated for each rainwater tank rebate recipient as the difference in households' water consumption before and after installation of rainwater tanks.

The data received from YVW showed the date the rebates were received by the 4391 households and not when the rainwater tanks were installed. In this case, it was assumed that the rainwater tanks were installed when the rebates were received. Household owners started receiving rebates in September 2006 until January 2009.

There might be cases when rainwater tanks were used before the rebates thus in the calculation of the water savings it was assumed that the "before installation" was from July 2005 to June 2006 and the "after installation" was from July 2009 to June 2010 (Table 2).

The average water consumption and water savings per household for each tank size are shown in Tables 3 and 4. Based on 4391 households, the average annual water consumption per household is $247 \mathrm{~kL}$ before the tank installation (July 2005 to June 2006) and $142 \mathrm{~kL}$ after the tank installation (July 2009 to June 2010). This resulted to average water saving of $105 \mathrm{~kL}$ per household per year. Since water restrictions and a strong water conservation campaign were in forced over the whole period of analysis, the calculated water savings may include savings due to these initiatives other than rainwater tanks.

As this saving covered all various sizes of tanks installed and different rebates for different tank sizes, water savings for each sizes of tanks were also calculated (Tables 3 and 4). Results revealed that the size of rainwater tanks chosen by household owners increases as their annual water consumption increases. Household owners with the lowest annual water consumption (204 kL) owned $600-1000 \mathrm{~L}$ tanks and those with the highest $(306 \mathrm{~kL})$ chose $>4501 \mathrm{~L}$ tanks. For households where rainwater tanks are connected to toilet and/or laundry, those with the lowest average annual consumption per household (216 kL) chose 2000-4999L tanks and those with the highest annual consumption (273 kL) owned $>5000 \mathrm{~L}$ tanks. Household owners tend to choose bigger sizes of rainwater tanks when uses also include toilet flushing and/or laundry.

Due to the limitation of the data, it could not be inferred if the choice of the rainwater tank size was based solely on the household's water consumption or if the roof size of the home, garden/lawn size and household size for households with indoor plumbing were also taken into consideration.

Table 2: $\quad$ Household water consumption record, YVW (in litres).

\begin{tabular}{|c|c|c|c|c|c|c|c|c|c|c|c|c|c|c|c|c|c|c|c|c|}
\hline \multicolumn{10}{|c|}{ Before } & \multicolumn{10}{|c|}{ Rebates Received } & \multicolumn{5}{c|}{ After } \\
\hline \multicolumn{10}{|c|}{ Jul 2005-Jun 2006 } & \multicolumn{10}{|c|}{ Sep 2006-Jan 2009 } & \multicolumn{5}{c|}{ Jul 2009-Jun 2010 } \\
\hline J J & S & J & A & J & S & J & A & J & S & J & A & J & S & J & A & J & S & J & A \\
\hline 42 & 40 & 63 & 59 & 37 & 44 & 56 & 41 & 29 & 34 & 43 & 40 & 30 & 32 & 41 & 36 & 29 & 29 & 34 & 38 \\
\hline
\end{tabular}


Table 3: $\quad$ Average water consumption per household for each tank size (kL).

\begin{tabular}{|c|c|c|c|c|c|c|c|c|c|}
\hline & No. of HH & \multicolumn{3}{|c|}{ Before Tank Installation } & \multicolumn{3}{|c|}{ After Tank Installation } \\
\cline { 3 - 10 } & & $7 / 05$ & $9 / 05$ & $1 / 06$ & $4 / 06$ & $7 / 09$ & $9 / 09$ & $1 / 10$ & $4 / 10$ \\
\hline All & 4391 & 51 & 49 & 76 & $\begin{array}{c}71 \\
(247)\end{array}$ & 31 & 32 & 37 & $\begin{array}{c}41 \\
(142)\end{array}$ \\
\hline 600-1000L & 237 & 42 & 40 & 63 & $\begin{array}{c}59 \\
(204)\end{array}$ & 29 & 29 & 34 & $\begin{array}{c}38 \\
(130)\end{array}$ \\
\hline 1001-1700L & 279 & 47 & 44 & 71 & $\begin{array}{c}62 \\
(224)\end{array}$ & 30 & 31 & 36 & $\begin{array}{c}40 \\
(137)\end{array}$ \\
\hline 1701-2250L & 855 & 49 & 46 & 73 & $\begin{array}{c}69 \\
(236)\end{array}$ & 31 & 33 & 38 & $\begin{array}{c}41 \\
(142)\end{array}$ \\
\hline 2251-3600L & 846 & 52 & 48 & 77 & $\begin{array}{c}74 \\
(253)\end{array}$ & 33 & 34 & 39 & $\begin{array}{c}44 \\
(151)\end{array}$ \\
\hline 3601-4500L & 211 & 50 & 50 & 84 & $\begin{array}{c}70 \\
(254)\end{array}$ & 31 & 35 & 41 & $\begin{array}{c}45 \\
(153)\end{array}$ \\
\hline >4501L & 409 & 61 & 57 & 97 & $\begin{array}{c}92 \\
(306)\end{array}$ & 35 & 37 & 45 & $\begin{array}{c}50 \\
(167)\end{array}$ \\
\hline 2000-4999L T\&orL & 507 & 47 & 45 & 64 & $\begin{array}{c}59 \\
(216)\end{array}$ & 26 & 27 & 31 & $\begin{array}{c}35 \\
(119)\end{array}$ \\
\hline >5000L TorL & 482 & 57 & 53 & 85 & $\begin{array}{c}77 \\
(273)\end{array}$ & 35 & 36 & 40 & $\begin{array}{c}43 \\
(154)\end{array}$ \\
\hline >5000L T\&L & 565 & 52 & 51 & 74 & $\begin{array}{c}67 \\
(244)\end{array}$ & 26 & 28 & 32 & $\begin{array}{c}35 \\
(122)\end{array}$ \\
\hline
\end{tabular}

Note: Figures in brackets are the average annual water consumption per household.

Table 4: $\quad$ Average water savings per household for each tank size (kL).

\begin{tabular}{|c|c|c|c|c|c|c|c|}
\hline Tank Size & HH & Jul & Sep & Jan & Apr & Annual Total & Percentage Savings (\%) \\
\hline All & 4391 & 20 & 16 & 39 & 30 & 105 & 42.5 \\
\hline 600-1000L & 237 & 14 & 10 & 29 & 21 & 74 & 36.3 \\
\hline 1001-1700L & 279 & 17 & 13 & 35 & 22 & 87 & 38.3 \\
\hline 1701-2250L & 855 & 18 & 13 & 35 & 28 & 95 & 40.2 \\
\hline 2251-3600L & 846 & 19 & 14 & 38 & 30 & 102 & 40.3 \\
\hline 3601-4500L & 211 & 19 & 15 & 43 & 24 & 101 & 39.8 \\
\hline >4501L & 409 & 25 & 20 & 51 & 42 & 139 & 45.4 \\
\hline 2000-4999L T\&orL & 507 & 21 & 18 & 33 & 24 & 96 & 44.4 \\
\hline >5000L TorL & 482 & 23 & 17 & 45 & 34 & 119 & 43.6 \\
\hline >5000L T\&L & 565 & 25 & 23 & 41 & 32 & 122 & 50.0 \\
\hline
\end{tabular}

\subsection{Payback period (PP)}

The Payback period (PP) is perhaps the simplest method of looking at one or more investments. The PP method focuses on recovering the cost of investments. PP represents the time that it takes for a capital project to recover its initial cost [12].

The PP calculation is as follows:

$$
P P=\frac{\text { Cost of Project }}{\text { Annual Cash Inflows }}
$$

The PP concept holds that all other things equal, the better investment is the one with the shorter payback. PP has the virtue of being easy to compute and easy to understand but that very simplicity carries weaknesses with it. It ignores any benefits that occur after the Payback period, and so does not measure total 
incomes. This is not an issue in this report however, since the objective is to determine how long will it take for individual households or government to recover the capital cost of the system.

Using Equation (1) to calculate the payback period of rainwater tanks for individual households, the cost of the project is considered to comprise of the tanks and installation costs as shown in Table 1, the cost of maintaining the rainwater tank of $\$ 20$ per year and the annual energy cost for those with indoor connections of 5 cents per kilolitre of water pumped [11].

The annual cash inflows were based on water savings. The cost of water saved was based on YVW pricing structure [15]. YVW uses the following "three tier block tariff" to charge for water use:

$\begin{array}{lll}\text { Block 1: } & 0-440 \text { litres per day } & =\$ 1.5343 / \mathrm{kL} \\ \text { Block 2: } & 441-880 \text { litres per day } & =\$ 1.8000 / \mathrm{kL} \\ \text { Block 3: } & 881+\text { litres per day } & =\$ 2.6594 / \mathrm{kL}\end{array}$

A discount rate of $6 \%$ was adopted as the increase in the cost of water over time. This is a conservative assumption since the prices of water increases by Melbourne Metropolitan water retailers (City West Water, Yarra Valley Water and South East Water) is 14\% in January 2009 prices [13]. The annual average GDP real growth rate for Australia for 2000-2010 is 3\% [14].

\subsection{Payback period for the household owners}

Based on the analysis undertaken the resulting PP ranges from 12 to 47 years depending on the tank size and the uses of rainwater (Figure 2). All those with connections to toilet and/or laundry take longer years to recover the capital and operating costs than those for outdoor purposes only. The longer payback periods are due to pumping and plumbing costs. However, in terms of water savings more can be achieved in the former than the latter (Figure 2).

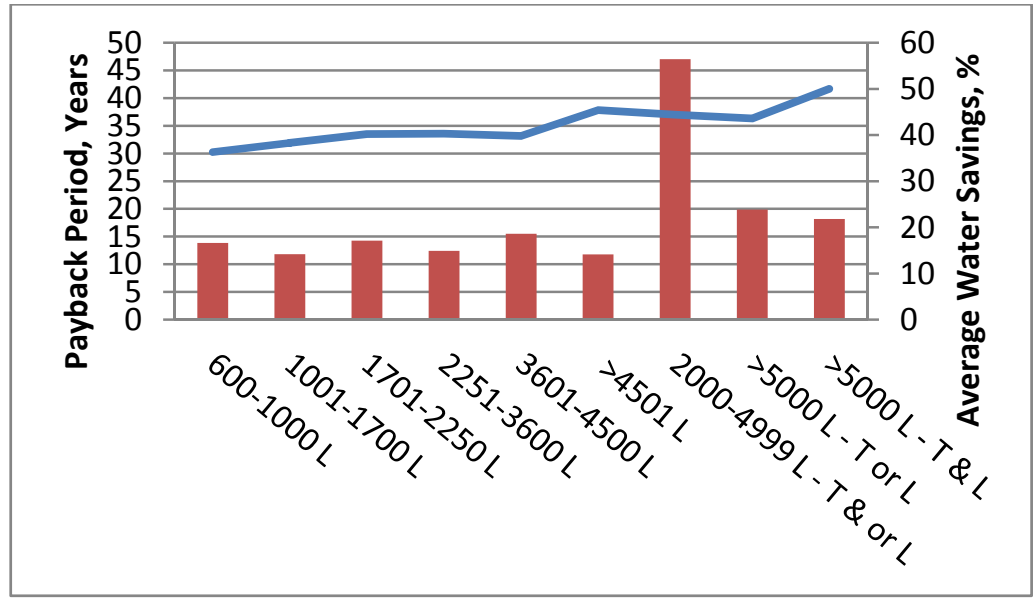

Figure 2: Payback periods (Years) for different rainwater tank sizes to the households and the corresponding percentage of water saved. 
All sizes except the 2000-4999L tank with connection to toilet and or laundry have payback periods of less than 20 years which is the expected life of rainwater tanks.

\subsection{Payback period for the government}

To determine the payback period of the scheme to the government, a set of control data was also analyzed. The control data contains a record of water usage from 4400 households who did not receive government rebates.

A comparison of the water usage revealed that the control group used less water than those that received government rebates before the installation of rainwater tanks but after the installation their water usage surpassed those that installed rainwater tanks (Figure 3). Some of the households within the control set might have installed rainwater tanks but did not avail the rebates from the government resulting to lower average consumption. However, this was not determined within this study.

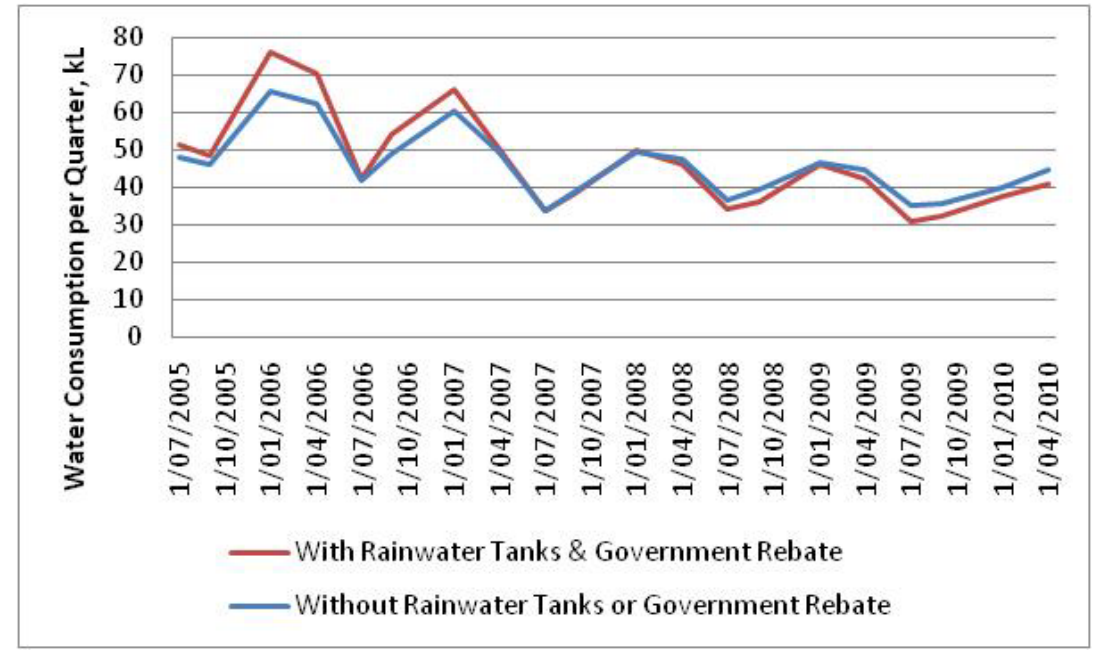

Figure 3: $\quad$ Comparison of water usage.

The water savings adopted as savings for the control group was calculated as the average water saved per household per year of those who received rebates (Method 1) and as the calculated average percentage water savings in Table 4 (Method 2). The payback period of the scheme to the government ranged from 1 to 12 years (Figure 4). Due to the limitations of the payback period approach, the results did not take into account the long term benefits of rainwater tanks, as there may be more water saved in these tanks than those without indoor plumbing. 


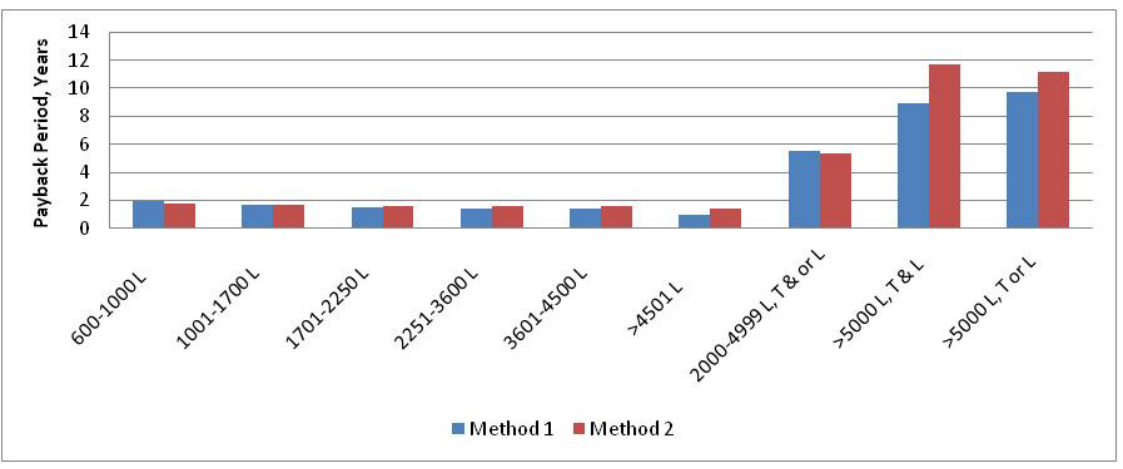

Figure 4: Payback periods (Years) for different rainwater tank sizes of the scheme to the government.

\section{Net present value analysis (NPV)}

Due to the limitations of the Payback Period approach, a NPV analysis was also conducted to determine the cost effectiveness of the scheme to the government. In this analysis, a discount rate of $6 \%$ and the expected life of the tank of 20 years were adopted. The price of water adopted was $\$ 1.13 \mathrm{~kL}^{-1}$, the long run marginal cost of supply augmentation to the Melbourne system.

Results revealed that with the rebates given, the rainwater tank size in the range of 2251-3600L without indoor plumbing yielded the highest NPV of $\$ 980,566$ (Table 5).

If the scheme will be extended to the 4400 households (control group), the analysis showed that tanks with indoor plumbing have lower NPVs than those without with the $>4500 \mathrm{~L}$ tank having the highest NPV of $\$ 7.32 \mathrm{M}$. Based on the simple analysis to determine the levelised cost of water from the water utility perspective the tank size $>4500 \mathrm{~L}$ yielded the lowest cost of $\$ 0.09 \mathrm{~kL}^{-1}$ (Table 5). This is calculated from the net present value cost of the scheme divided by the present value of the total amount of water saved.

Table 5: $\quad$ Net present value for each rainwater tank size.

\begin{tabular}{|c|c|c|c|c|c|c|c|c|}
\hline Tank Size & HH & $\begin{array}{c}\text { Annual } \\
\text { Total }\end{array}$ & $\begin{array}{c}\text { Savings } \\
(\%)\end{array}$ & $\begin{array}{c}\text { NPV } \\
(\$)\end{array}$ & $\mathrm{HH}$ & $\begin{array}{c}\mathrm{NPV}^{1} \\
(\$ \mathrm{M})\end{array}$ & $\begin{array}{c}\mathrm{NPV}^{2} \\
(\$ \mathrm{M})\end{array}$ & $\begin{array}{c}\$ \\
\mathrm{~kL}^{-1}\end{array}$ \\
\hline 600-1000L & 237 & 74 & 36.3 & 191,760 & 4400 & 3.56 & 3.94 & 0.18 \\
\hline 1001-1700L & 279 & 87 & 38.3 & 272,753 & 4400 & 4.03 & 4.20 & 0.15 \\
\hline 1701-2250L & 855 & 95 & 40.2 & 913,426 & 4400 & 4.07 & 4.44 & 0.14 \\
\hline 2251-3600L & 846 & 102 & 40.3 & 980,566 & 4400 & 5.10 & 4.45 & 0.13 \\
\hline 3601-4500L & 211 & 101 & 39.8 & 247,297 & 4400 & 5.16 & 4.38 & 0.13 \\
\hline >4501L & 409 & 139 & 45.4 & 680,798 & 4400 & 7.32 & 5.10 & 0.09 \\
\hline $\begin{array}{c}\text { 2000- } \\
\text { 4999LT\&orL }\end{array}$ & 507 & 96 & 44.4 & 377,338 & 4400 & 3.28 & 3.43 & 0.45 \\
\hline >5000L TorL & 482 & 119 & 43.6 & 303,370 & 4400 & 2.77 & 1.57 & 0.66 \\
\hline >5000L T\&L & 565 & 122 & 50.0 & 335,725 & 4400 & 2.61 & 1.94 & 0.71 \\
\hline
\end{tabular}

Note: $\mathrm{NPV}^{1}$ was based on Method 1 and $\mathrm{NPV}^{2}$ on Method 2 as described in Section 4.6. 


\section{Conclusions}

Based on the available data and the analysis undertaken it can be concluded that:

1. The sizes of rainwater tanks installed increases as the average household consumption increases and as the system includes connections to toilets and laundry. Due to unavailability of information, the basis of such choice was not determined.

2. Installation of rainwater tanks contributed to the $42.5 \%$ reduction in household water consumption (105 kL per year) over the whole sample. Other contributors may include the installation of water efficient appliances, Target 155 and other water conservation programs implemented during the period of analysis.

3. Larger rainwater tanks and those with indoor plumbing for toilet flushing and laundry yielded higher water savings than smaller tanks (up to $50 \%$ of average household water consumption or $122 \mathrm{~kL} /$ year).

4. All sizes of rainwater tanks analyzed in this study except the 2000L-4999L tanks have payback periods of less than 20 years for the household owners. For the government, the payback periods ranged from 1 to 12 years.

5. With the rebates given, the 2251-3600L rainwater tank without indoor plumbing yielded the highest NPV in water savings of $\$ 980,566$.

6. If the government extend the scheme to the 4400 households, the rainwater tank size $>4500 \mathrm{~L}$ had the highest NPV in water savings of $\$ 7.32 \mathrm{M}$ and a lowest levelised water cost of $\$ 0.09$ per $\mathrm{kL}$.

\section{Recommendations}

To date most of the studies relied on hypothetical studies. This study has the advantage of having a large number of households with actual water consumption information. However, some of the parameters that are needed to properly develop a tool that will assist in determining the most cost effective rainwater tank size in individual households were not included in this enormous set of data. It is therefore recommended that information such as lawns/gardens' size, roof size and household size relating to each individual household in this study be collected and further analyzed.

\section{Acknowledgement}

Yarra Valley Water provided all the data used in this study.

\section{References}

[1] 3218.0-Regional Population Growth, Australia, 2007-08; ABS. http://www.abs.gov.au/ausstats/abs@.nsf/Products/3218.0 2007-08 Main+ Features Victoria?OpenDocument\#LOCALGOVERNMENTAREAPOPU LATIONS viewed 14 Dec 2010. 
[2] Melbourne Atlas 2006-Housing. Department of Planning and Community Development, Victoria, Australia; DPCD. http://www.dpcd.vic.gov.au/ home/publications-and-research/urban-and-regional-research/melbourneatlas-2006/housing viewed 14 Dec 2010.

[3] Melbourne Water 2009 Water Plan; Melbourne Water. http://www.esc.vic.gov.au/public/Water/Consultations/Melbourne+metropo litan+water+price+review+2009-10+to+2012-13/Melbourne+Water.htm viewed 14 Dec 2010.

[4] Water Resources Strategy Committee for the Melbourne Area. Strategy Directions Report: Stage 2 in developing a Water Resources Strategy for the Greater Melbourne area. 132pp, 2002.

[5] Rahman, A., Dbais, J. \& Imteaz, M., Sustainability of Rainwater Harvesting Systems in Multistorey Residential Buildings. American Journal of Engineering and Applied Sciences, 3(1):889-898, ISSN 19417020, 2010.

[6] Coombes, P. \& Kuczera, G., Analysis of the performance of rainwater tanks in Australian capital cities. Proceedings of the 28th International Hydrology and Water Resources Symposium, Engineers Australia, 10-14 November 2003, Wollongong, New South Wales, 2003

[7] Villarreal, E. L. \& Dixon, A, Analysis of a rainwater collection system for domestic water supply in Ringdansen, Norrköping, Sweden. Build. Environ. 40, pp. 1174-1184, 2005

[8] Tam, V. W. Y., Tam, L. \& Zeng, S. X.. Cost effectiveness and tradeoff on the use of rainwater tank: an empirical study in Australian residential decision-making, Resources, Conservation and Recycling 54, pp. 178-185, 2009

[9] The economics of rainwater tanks and alternative water supply options. Prepared for the Australian Conservation Foundation, Nature Conservation Council (NSW) and Environment Victoria by Marsden Jacob Associates. 2007.

[10] Rainwater Tanks Direct. http://www.rainwatertanksdirect.com.au/rainwater-tanks/ viewed 19 Dec 2010.

[11] Coombes, P. 2004, 'Rainwater tanks', in Water Sensitive Resource Kit for the Sydney Region, Upper Parramatta River Catchment Trust, New South Wales.

[12] http://www.valuebasedmanagement.net/methods_payback_period.html viewed 16/02/2011

[13] Essential Services Commission Victoria. 2009. Metropolitan Melbourne Water Price review 2009 - Final Decision.

[14] World Economic Outlook, April 2010, International Monetary Fund http://www.business.nsw.gov.au/invest-in-nsw/about-nsw/economic-andbusiness-climate/gross-domestic-product-growth-rates viewed 2 March 2011.

[15] YVW 2011. Water Usage Charges http://www.yvw.com.au/ Home/Youraccount/Paying/Pricingandcharges/Waterusagecharges/index.ht m viewed 01 March 2011. 